\title{
Erratum to: Mapping mountain areas: learning from Global, European and Norwegian perspectives
}

\author{
Martin F. PRICE1 ${ }^{*}$ (D) http://orcid.org/oooo-0oo2-7430-7262; $৯$ e-mail: martin.price@perth.uhi.ac.uk \\ Tor ARNESEN2 (iD http://orcid.org/oooo-0003-4803-0682; e-mail: tor.arnesen@ostforsk.no \\ Erik GLØERSEN3 (iDhttp://orcid.org/oooo-0oo3-1200-3543; e-mail: erik.gloersen@spatialforesight.eu \\ Marc J. METZGER 4 iD http://orcid.org/oooo-0oo2-5119-5894; e-mail: marc.metzger@ed.ac.uk \\ * Corresponding author \\ 1 Centre for Mountain Studies, Perth College, University of the Highlands and Islands, Crieff Road, Perth PH1 2NX, \\ United Kingdom \\ 2 Mountain Research Programme, Eastern Norway Research Institute, 2600 Lillehammer, Norway \\ 3 Spatial Foresight, Territorial Policy Support and Research, 75013 Paris, France \\ 4 Research Institute of Geography and the Lived Environment, School of GeoSciences, University of Edinburgh, \\ Edinburgh EH8 9XP, United Kingdom
}

\begin{abstract}
Citation: Price MF, Arnesen T, Gløersen E, Metzger MJ (2022) Erratum to: Mapping mountain areas: learning from Global, European and Norwegian perspectives. Journal of Mountain Science 19(6). https://doi.org/10.1007/s11629-0185008-0
\end{abstract}

(C) The Author(s) 2022

Erratum to: J. Mt. Sci. (2018) 15

https://doi.org/10.1007/s11629-018-4916-3

The article Mapping mountain areas: learning from Global, European and Norwegian perspectives, written by Martin F. PRICE, Tor ARNESEN, Erik GLØERSEN and Marc J. METZGER, was originally erroneously published electronically on the publisher's internet portal (currently SpringerLink) on May $21^{\text {st }} 2018$ without open access.

When the mistake was discovered the copyright of the article changed in June 2018 to (C) The Author(s) 2018 and the article is forthwith distributed under the terms of the Creative Commons Attribution 4.0 International License (http://creativecommons.org/licenses/by/4.o/), which permits use, duplication, adaptation, distribution and reproduction in any medium or format, as long as you give appropriate credit to the original author(s) and the source, provide a link to the Creative Commons license, and indicate if changes were made. The original article has been corrected.

\section{Open Access}

This article is distributed under the terms of the Creative Commons Attribution 4.0 International License (http://creativecommons. org/licenses/by/4.o/), which permits unrestricted use, distribution, and reproduction in any medium, provided you give appropriate credit to the original author(s) and the source, provide a link to the Creative Commons license, and indicate if changes were made. 